\title{
DIVERSITY AND ECOLOGY OF DIATOMS IN NORTHWEST OF ALGERIA: CASE OF EL-HAMMAM STREAM AND ESTUARY OF CHELIFF RIVER
}

\author{
NEHAR, B. ${ }^{1 *-B L A N C O}, \mathrm{~S}{ }^{2}-$ HADJADJ-AOUL, $S .{ }^{1}$ \\ ${ }^{1}$ Laboratory of Plant Ecology, Department of Biology, Faculty of Science, University of Es- \\ Senia, \\ 31000 Oran, Algeria. \\ email:seghirhadjadj@yahoo.fr \\ ${ }^{2}$ Department of Biodiversity and Environmental Management, University of León, \\ E-24071 León, Spain. \\ email:saul.lanza@unileon.es \\ * Corresponding author: \\ e-mail: neharbenameur@yahoo.fr \\ (Received 26 $6^{\text {th }}$ Dec 2013; accepted 14 $4^{\text {th }}$ Aug 2014)
}

\begin{abstract}
Ecological research on algae from Algeria and in particular on freshwater and estuarine diatoms remains insufficient. The aim of our work is to contribute to the taxonomy and ecology of benthic diatoms from freshwaters and estuaries in Algeria. For this purpose, we studied two sites of water courses in north-western Algeria: El-Hammam stream at Mascara and the estuary of Cheliff river at Mostaganem. Our inventory of benthic diatoms during dry season at the middle of El-Hammam stream during April, June and August 2010 led to the identification of 44 cosmopolitan species, while 30 species occurred at the mouth of Cheliff river. 10 taxa were recorded for the first time in Algeria. Diversity values (Species richness, Shannon's index and Equitability index) for the two study sites are generally medium to low. The results of the 17 diatom-based metrics tested show that ROTT trophic index (TID) and the Trophic Diatom Index (TDI) best mirrored water quality, but a revision of taxa autecological values is required.
\end{abstract}

\section{Introduction}

The earliest studies on the algal flora of Algeria date back to 1799 with the work of Desfontaines (Baudrimont, 1971a), after that, first researches on Algerian diatom flora were performed by Montagne (1846), Ehrenberg (1854). The works of Baudrimont (1974) are remarkable contributions to the ecology of diatoms in Algeria. He has recorded 356 species, varieties and forms during his research on diatoms of inland waters in Algeria, estimating that this inventory represents only $17.5 \%$ of the world's known flora in 1968. Since then, the global number of described taxa has increased exponentially while the flora of Algerian diatoms has not changed apart from recent studies including the work of Al-Asadi et al. (2006), the monograph by Lange-Bertalot et al. (2009) identifying four new Navigiolum from samples collected in Algerian ephemeral rock pools ("Gueltas") and the papers of Chaïb et al. (2011) and Chaïb and Tison-Rosebery (2012) on samples collected from wadi (stream) Kebir-East, North-East Algeria.

Besides their floristic interest, several authors have studied diatoms as biological proxies for water quality, discussing their performance as surrogates for saprobity, trophic status, acidity, etc. Benthic diatoms are now considered key organisms for 
monitoring river ecological quality in several European countries (European Union, 2000). In Algeria apart from the study of Chaïb and Tison-Rosebery (2012), to our knowledge no attempt of diatom-based environmental monitoring has been performed to date in Algerian aquatic ecosystems, evidencing the lack of accurate ecological information linked to available diatom data.

This work presents two inventories of benthic diatoms in two different hydrosystems in northwestern Algeria: the estuary of Cheliff river (Brackish water) at Mostaganem and in the middle of El-Hammam stream (freshwater) at Mascara. The results of this study will contribute to the database of Algerian benthic diatoms. We also test the performance of 17 diatom indices in order to provide a scientific basis for the implementation of diatom-based monitoring programs in this region.

\section{Material et methods}

\section{Study sites}

Algeria includes many arid and semi-arid areas which suffer from long periods of drought and severe water shortages. Four stations at two sites have been chosen:

a) The site $\mathrm{S} 1$ in the middle of El-Hammam stream (Fig. 1), located northwest of Algeria, municipality of Bouhanifia, region of Mascara. El-Hammam stream is subject to a semi-arid climate with an annual average temperature of $16.6^{\circ} \mathrm{C}$ and a precipitation for the whole basin estimated at $385.3 \mathrm{~mm}$. Its watershed is part of the great Makta's watershed; it is limited by the mountains of Beni-Chougrane north and massive of Siada south. Two stations were chosen at this site: $\mathrm{H} 1\left(35^{\circ} 17^{\prime} 58.70^{\prime \prime} \mathrm{N}, 0^{\circ} 2^{\prime} 48.26^{\prime \prime} \mathrm{W}, 231\right.$ $\mathrm{m}$ a.s.1.) and $\mathrm{H} 2\left(35^{\circ} 18^{\prime} 52.06^{\prime \prime} \mathrm{N}, 0^{\circ} 3^{\prime} 4.45^{\prime \prime} \mathrm{W}, 226 \mathrm{~m}\right.$ a.s.1.) at a distance of about $2.26 \mathrm{~km}$ and $4.24 \mathrm{~km}$ respectively downstream of the dam of Bouhanifia.

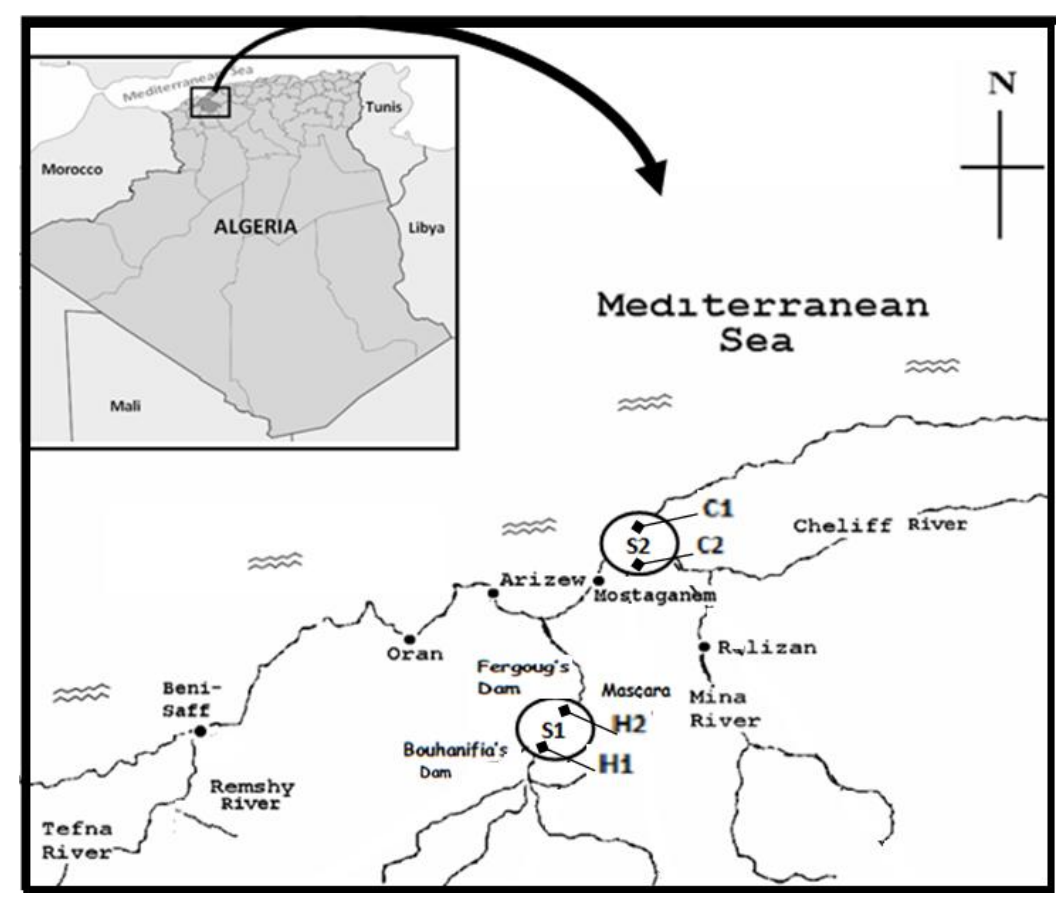

Figure 1. Location of the four study sites H1, H2 at the site S1 at El-Hammam stream and C1, $C 2$ at the site $S 2$ at the mouth of Cheliff river. 
b) Site S2 belongs to the estuary of Cheliff river (Fig. 1), the largest watercourse in Algeria, located northwest of the country, $700 \mathrm{~km}$ long, it passes through several wilayas including Mostaganem, Relizan, Ain-Aldeffla and Cheliff (Al-Asadi et al., 2006), it rises in the Tell atlas and flows $13 \mathrm{~km}$ east of the city of Mostaganem (Cheliffbeach). The zone is characterized by hot summers and cool winters, with temperatures ranging from $10.41{ }^{\circ} \mathrm{C}$ in January to $24.06{ }^{\circ} \mathrm{C}$ in August, while rainfall varies from 1.37 to $74.59 \mathrm{~mm}$ from July to December (Al-Asadi et al., 2006). Two stations were chosen near the mouth: $\mathrm{C} 1$ ( $36^{\circ} 2^{\prime} 14.47^{\prime \prime} \mathrm{N}, 0^{\circ} 8^{\prime} 10.00^{\prime \prime}$, sea level) and $\mathrm{C} 2\left(36^{\circ} 2^{\prime} 0.17^{\prime \prime} \mathrm{N}, 0^{\circ}\right.$ $8^{\prime} 39.50 "$ ", sea level) at a distance of about $360 \mathrm{~m}$ and $1.21 \mathrm{~km}$ respectively from the Mediterranean Sea.

\section{Collection of benthic diatoms}

Benthic diatoms were sampled during low flow periods during the months of April, June and August in the year 2010. Different natural substrates immersed in water were used for the collection of periphyton depending on sampling conditions, access and availability of substrates (Kelly et al., 1998; Prygiel and Coste, 2000; Taylor et al., 2007b). In total, 24 samples were collected. The surfaces of the natural substrates (pebbles, cobbles and stems) collected from watercourses were brushed using a toothbrush to remove periphyton containing diatoms, in the case of the filamentous algae; diatoms were collected after shaking algae in sachets containing clean medium water.

\section{Identification of benthic diatoms}

Benthic diatoms were collected in separate bottles and stored in the field with $10 \%$ of formalin neutralized the sample as treated with boiling hydrogen peroxide $\left(\mathrm{H}_{2} \mathrm{O}_{2}\right.$ at $30 \%$ ) for 10 minutes to degrade organic matter and for 5 minutes with boiling hydrochloric acid $\mathrm{HCl} 35 \%$. Samples were then subjected to a series of centrifugations for $5 \mathrm{~min}$ at $2500 \mathrm{rpm}$ and a succession of cleanings with distilled water. An aliquot of the cleaned sample was deposited on a coverslip, dehydrated by drying and mounted in the resin refractive Naphrax (Northern Biological Supplies Ltd., England, refractive index = 1.74), (Hasle and Fryxell, 1970; Prygiel and Coste, 2000). Microscopic examination of permanent slides were made using an optical microscope LEICA DM 5000 type B in differential interference contrast (DIC), diatom species were identified at a magnification X1000 with immersion oil, a minimum of 400 diatom valves were identified in each slide following usual references (Krammer and Lange-Bertalot, 1988, 1986, 1991a, 1991b, 2000 ; Prygiel and Coste, 2000; Bate et al., 2004; Taylor et al., 2007a; Lavoie et al., 2008; Blanco et al., 2010; etc.).

\section{Physicochemical parameters}

Main limnological parameters were provided by the National Agency of Water Resources (ANRH, 2010) at two stations: the dam of Bouhanifia (upstream of Elhammam) and station Hacine (downstream of El-hammam at around $8 \mathrm{~km}$ upstream of Fergoug's dam). Additionally, temperature, $\mathrm{pH}$ and conductivity were measured at the other locations. These three parameters were measured in situ by a thermometer (liquid in glass), digital pH-meter type PHT-01 ATC Voltcraft and conductimeter type LWT01 Voltcraftwe. 


\section{Statistical analysis}

Data were analysed for correlation and correspondence analyses (CA). A Correspondence Analysis (CA) was used to explore the distribution of diatom taxa in the different stations studied. The relationships between the different metrics calculated were assessed by means of Pearson's correlation coefficients. Both were calculated using XLStat software v. 2013 (Addinosoft, 2013). Diatom indices were calculated using Omnidia software (Lecointe and Coste, 1993).

\section{Results and Discussion}

The inventory of benthic diatoms at both sites consisted of a total of 56 taxa 44 of them found the middle of El-Hammam stream and 30 taxa at the mouth of Cheliff river, including 18 taxa in common to both sites. Ten taxa were recorded for the first time in Algeria (Table 1).

During the low-flow periods in the months of April, June and August, the fresh water of station $\mathrm{H1}$ at El-Hammam stream was characterized by the dominance (> 20\%) of Achnanthidium minutissimum, Cyclotella ocellata, C. meneghiniana, Nitzschia frustulum and $N$. palea, while the station $\mathrm{H} 2$ was characterized by the dominance of Achnanthidium saprophilum, Navicula cryptotenelloides, N. erifuga and Nitzschia palea. Other frequent taxa (5-20\%) at site H1 were Achnanthidium saprophilum and Surirella brebissonii, while at the site $\mathrm{H} 2$ Achnanthidium exiguum, Cyclotella meneghiniana, Fragilaria nana, Gomophonema parvulum, Navicula frustulum, $N$. recens and, $N$. veneta appeared as subdominant species.

Most species recorded at El-Hammam stream are known to be cosmopolitan, being common in European freshwaters with a slight salinity and alkaline content, as remarked by Baudrimont (1974) in his study of taxa from arid and semi-arid areas of Algeria inculding the region of Mascara. Most of these taxa were already recorded by some authors in north Algeria (Petit, 1895; Baudrimont, 1974; Al-Asadi et al., 2006; Chaïb et al., 2011; Chaïb and Tison-Rosebery, 2012). Baudrimont (1974) took samples at Hammam Bouhanifia from the thermal spring of El-Hammam stream with water above $50{ }^{\circ} \mathrm{C}$, recording Cocconeis pediculus and Cyclotella meneghiniana, but no samples had been takes to date from El-Hammam stream where we record for the first time the presence of Craticula buderi, Conticribra weissflogii, Cymbopleura incerta, Denticula kuetzingii, Fragilaria nana, Navicula phyllepta, Navicula simulata and Nitzschia perminuta.

Concerning the saline waters, during the sampling period at the estuary of Cheliff river the dominant taxa (> 20\%) in both stations C1 and C2 were Amphora sp. and Berkeleya sp.2. The most abundant taxa (5-20\%) in both stations were Achnanthes minutissimum var. gracillima, Berkeleya sp.1 and Navicula phyllepta. Cyclotella meneghiniana was found abundant at station $\mathrm{C} 1$ and Achnanthes minutissimum var gracillima, Cylindrotheca closterium, Halamphora coffeaeformis and Nitzschia incerta at station C2. All the taxa recorded at the estuary of Cheliff river are known to be cosmopolitan. Except for a few refrences on marine diatoms from saline waters from Algeria like Chott and Sebkha (Petit, 1895; Amosse, 1941; Baudrimont, 1970, 1971a, 1974) to our knowledge no further papers study Algerian estuarine diatoms, thus we cite for the first time the following taxa: Achnanthes minutissima var gracillima, Craticula buderi, Gyrosigma scalproides, Navicula phyllepta. 
Table 1. Average frequency of diatoms recorded in different stations at two sites in the middle of El- Hammam stream and at the mouth of Cheliff river. **: Taxa preceded by asterisk were recorded for the first time in Algeria.

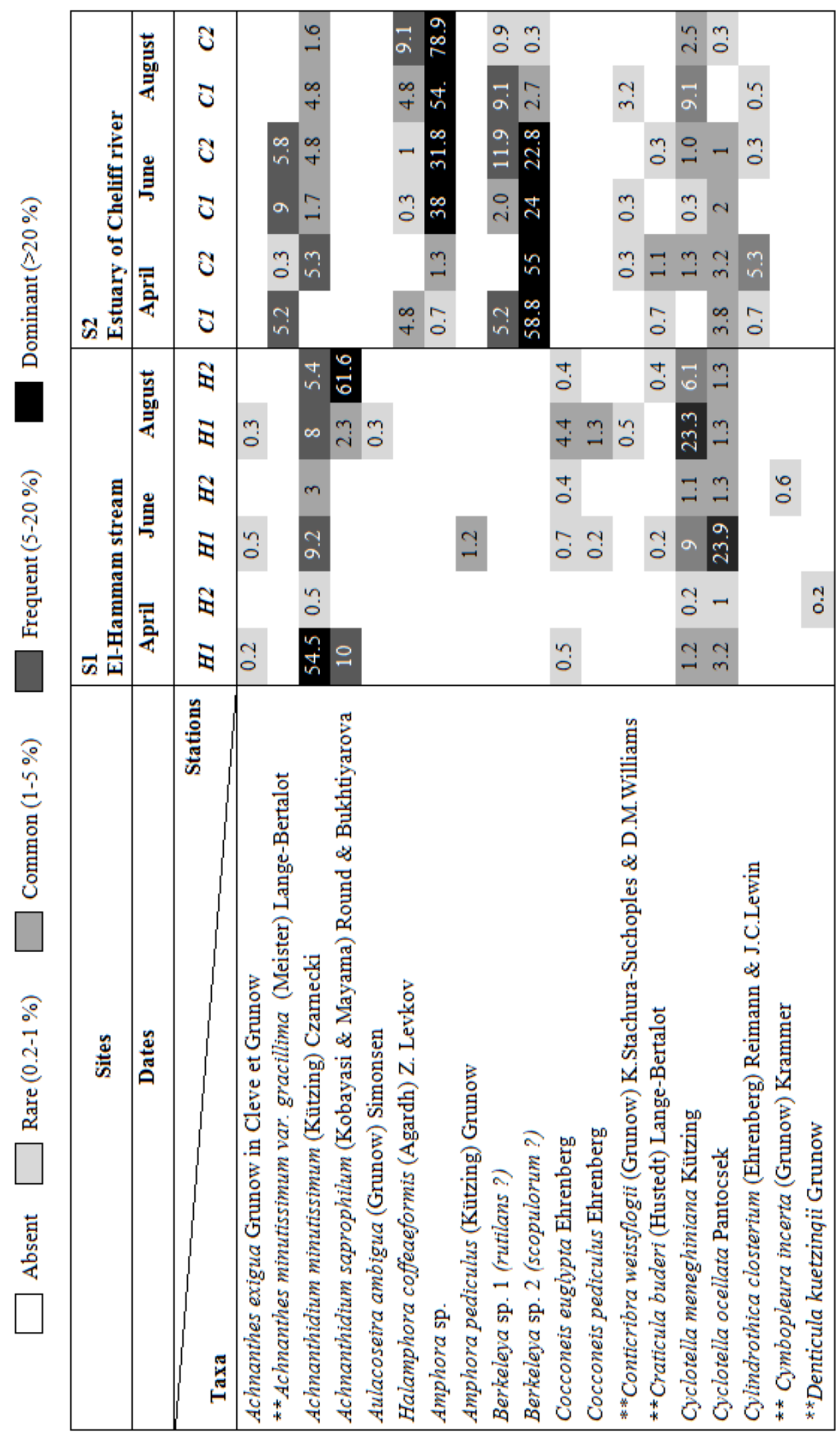

APPLIED ECOLOGY AND ENVIRONMENTAL RESEARCH 13(1): 37-52.

http://www.aloki.hu • ISSN 15891623 (Print) • ISSN 17850037 (Online) 


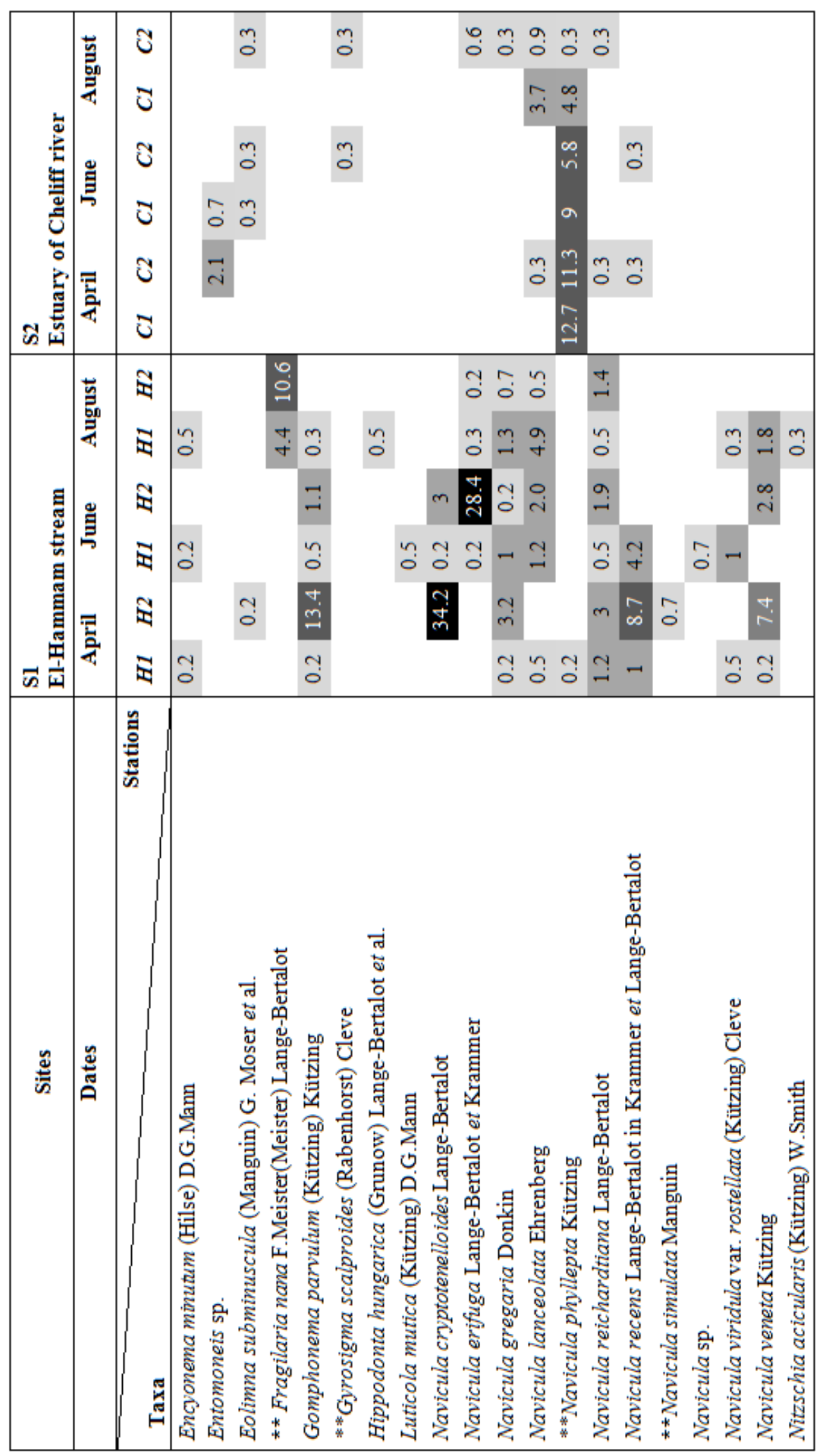




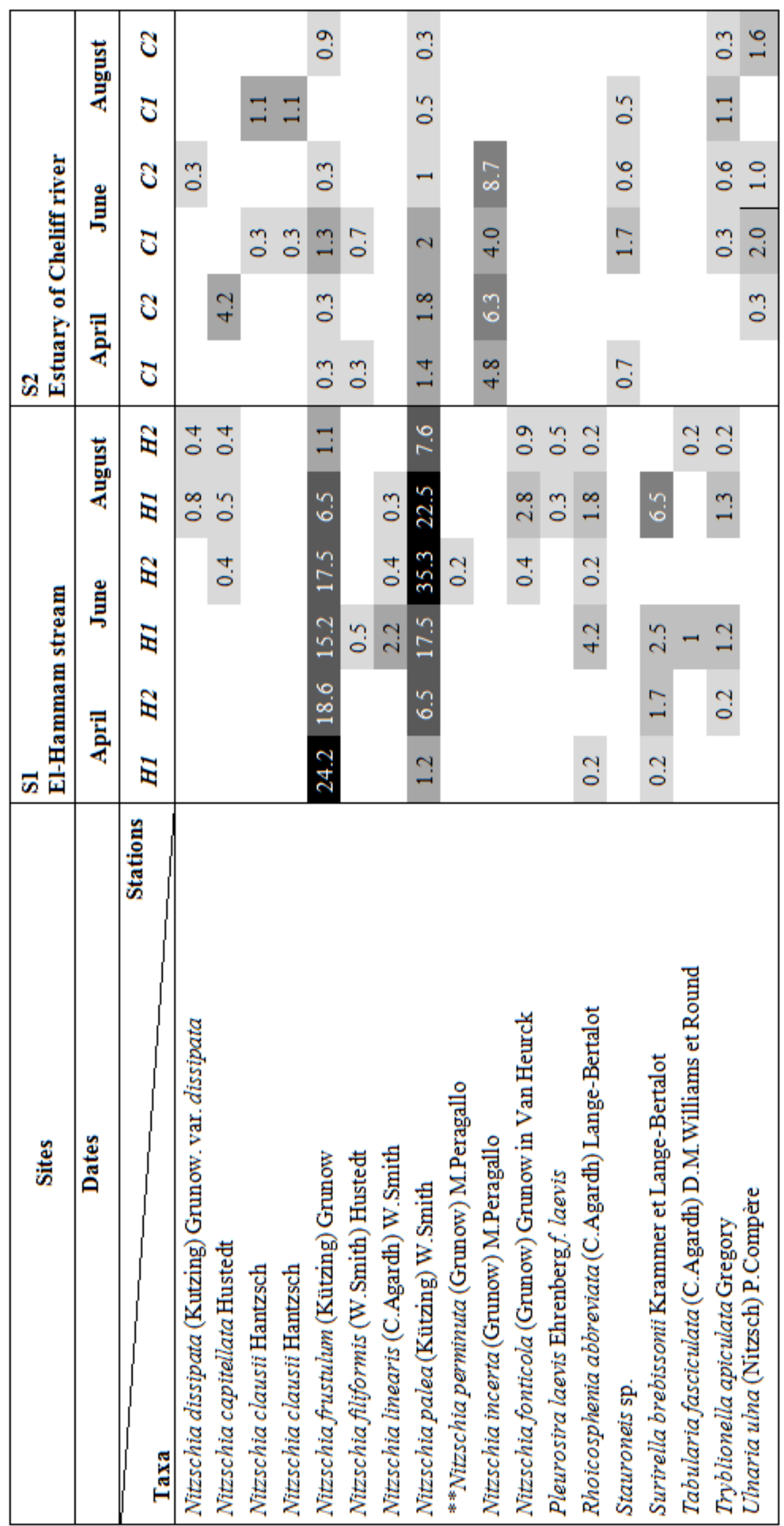

APPLIED ECOLOGY AND ENVIRONMENTAL RESEARCH 13(1): 37-52.

http://www.aloki.hu • ISSN 15891623 (Print) • ISSN 17850037 (Online) 
Concerning diversity indices, the values of stand structure metrics (species richness $\mathrm{S}$, Shannon's diversity $\mathrm{H}_{a}$ and evenness $\mathrm{E}$ ) at both sites are generally low, with an average Shannon's diversity not exceeding 2.5 bits (Table 2). At El-Hammam stream, the diatom communities at stations $\mathrm{H} 1$ April and $\mathrm{H} 2$ August are less balanced and diversified compared to others stations. Station H1 April was dominated by Achnanthidium minutissimum (55\%) and Nitzschia frustulum (24\%) wich influenced negatively Shannon's diversity "H $\alpha$ " and evenness "E". Chaïb and Tison-Rosebery (2012) noted that Achnanthidium minutissimum represented up to $75 \%$ of the community abundance during the summer at a station of Kebir-East stream (North-est of Algeria). Mean calculated values of diversity index at Kebir-East stream in summer were around $\mathrm{E}=0.7$ and $\mathrm{H} \alpha=3.7$, being $\mathrm{E}=0.6$ and $\mathrm{H} \alpha=1.9$ at El-Hammam stream.

Table 2. Shannon-weaver diversity index and equitability of El-Hammam stream and Cheliff's estuary.

\begin{tabular}{|l|lllllll|}
\hline \multirow{2}{*}{ El-Hammam Stations } & \multicolumn{3}{|c}{ April } & \multicolumn{3}{c|}{ June } & \multicolumn{2}{c|}{ August } \\
\cline { 2 - 7 } & $\boldsymbol{H 1}$ & $\boldsymbol{H 2}$ & $\boldsymbol{H 1}$ & $\boldsymbol{H 2}$ & $\boldsymbol{H 1}$ & $\boldsymbol{H 2}$ \\
\hline Shannon -weaver diversity index $\left(\mathrm{H}_{\alpha}\right)$ & 1.41 & 1.95 & 2.39 & 1.80 & 2.51 & 1.48 \\
Equitability (E) & 0.48 & 0.72 & 0.73 & 0.61 & 0.73 & 0.49 \\
Species richness (S) & 19 & 16 & 27 & 19 & 30 & 20 \\
\hline Estuary of Cheliff Stations & $\boldsymbol{C 1}$ & $\boldsymbol{C} \mathbf{2}$ & $\boldsymbol{C 1}$ & $\boldsymbol{C} \mathbf{2}$ & $\boldsymbol{C 1}$ & $\boldsymbol{C} \mathbf{2}$ \\
\hline Shannon -weaver diversity index $\left(\mathrm{H}_{\alpha}\right)$ & 1.53 & 1.72 & 1.96 & 1.85 & 1.71 & 0.95 \\
Equitability (E) & 0.58 & 0.59 & 0.65 & 0.60 & 0.65 & 0.33 \\
Species richness (S) & 14 & 19 & 20 & 21 & 14 & 18 \\
\hline
\end{tabular}

At Cheliff river, station August C2 shows clearly the most unbalanced and less diversified assemblage, with $\mathrm{E}=0.33$ and $\mathrm{H} \alpha=0.95$. This was characterized by the abundance (78\%) of Amphora sp. (Table 1). In general, diatom diversity at the estaury of Cheliff river (around $\mathrm{E}=0.5$ and $\mathrm{H} \alpha=1.6$ ) was influenced by the presence of brackish taxa such Berkeleya sp. 2 and Amphora sp., ecological studies of most species of the genus Amphora recorded at Algeria were from saline and brackish waters such Chott (Baudrimont, 1970, 1971a, 1974). However, the ecology of the genus Berkeleya in Algerian saline waters is still uknown (Petit, 1895; Amosse, 1941). Rovira et al. (2009) studied the diversity of periphytic diatom community in a Mediterranean salt wedge estuary at the Ebro Estuary (Spain), noting the most abundant genera (considering all species) were Cocconeis (23\%), followed by Navicula (21\%), Nitzschia (17\%) and Tabularia (11\%), with a mean value of $\mathrm{H} \alpha=3.4$ and species richness $\mathrm{S}=39$, in clear contrast with our results. The diatom community at estuary of Cheliff river was less diversified, with a mean $H \alpha=1.6$ and $S=18$, these values probabli related to mineral and organic pollutants accumulated in this area (Kies, 2009). Al-Asadi et al. (2006) studied the Cheliff river, finding that diatoms showed less dominance than in the Mina river in northwestern Algeria.

Concerning organic pollution, ecoligical studies in Algerian waters have been focused only on inorganic components, with no previous mesurements of parameters such as biological or chemical oxygen demand. The saprobity status of Algerian waters has not been properly assessed either. We calculated the Organic Pollution Index or 
"Indice de Pollution Organique IPO" (Leclercq and Maquet, 1987) from physicochemical data given by National Agency of Water Ressources of Algeria (Table 3 ) in summer of 2010 at El-hammam stream upstream of fargoug's dam which value of "IPO" show that water quality was strongly polluted by organic materials (IPO: from 2.0 to 2.9). Also we calculated the same index at Kebir-East stream in summer 2007 from physicochemical data published by Chaïb and Tison-Rosebery (2012) which water was also strongly polluted by organic materials (IPO: from 2.0 to 2.9). Using this metric, Bahroun and Kherici Bousnoubra (2011) at the Kebir-East stream in 2004-2005, indicated that water was extremely polluted by organic materials.

According to the classification of Van Dam et al. (1994), the most frequent taxa at El-hammam stream were $\beta$-mesosaprobous (42.7\%) and polysaprobous (30.7\%), compared to Kebir-East stream were most taxa recorded as frequent by Chaïb and Tison-Rosebery (2012) were $\beta$-mesosaprobous to $\alpha$-meso-/polysaprobous (Achnanthidium minitissimum, Amphora pediculus, Gomphonema parvulum, Navicula gregaria, Nitzschia frustulum, Eolimna subminuscula) except for Cyclotella ocellata (oligosaprobous) and Nitzschia palea (polysaprobous). While species abundance at ElHammam stream was a bit different additional to Achnanthidium minitissimum, Cyclotella ocellata, Nitzschia frustulum, Nitzschia palea we recorded also Achnanthidium saprophilum (polysaprobous), Cyclotella meneghiniana and Navicula cryptotenelloides ( $\beta$-mesosaprobous). The abundance of Cyclotella ocellata at ElHammam stream reached up (23\%) at H1 June and was not as stable as that of Nitzschia frustulum and $N$. palea during the summer at El-Hammam stream probably because high oxygen concentrations (128\% stauration) recorded near this station at dam of Bouhanifia (Table 3). The abundance of Nitzschia frustulum and N. palea was also noted by Fawzi et al. (2001) at wadi Hassar from Morocco, under semi-arid climate with oceanic influence at, where these two species indicated an important degree of organic pollution.

With respect to the trophic status, the communities at stations of El-Hammam stream were generally dominated by eutrophentic (42.5\%) and hypereutrophentic taxa (28\%), Dominant species (>20\%) such as Nitzschia frustulum at H1 April, Navicula erifuga at $\mathrm{H} 2$ June and Cyclotella meneghiniana at H1 August were eutrophilous, but hypereutrophilous taxa such as Achnanthidium saprophilum at $\mathrm{H} 2$ August, or Nitzschia palea at $\mathrm{H} 2$ June and $\mathrm{H} 1$ August also occured, thereby indicating that these areas were impacted by nutrient inflows, presumably related to adjacent anthropogenic activities including agriculture. The same pattern was observed at Kebir-East stream by Chaib and Tison-Rosebery (2012) with eutrophentic taxa representing 52.5\% of the community.

Concerning conductivity and salinity levels, most dominant taxa at El-Hammam stream were fresh-brackish taxa $(55.7 \%)$ with salinity optima under 0.825 PSU according to the classification of Van Dam et al. (1994) and brackish-fresh taxa (34.9\%) with salinity optima of $0.825-1.65$ PSU.

In general, the same dominant species were recorded at Kebir-East stream by Chaïb and Tison-Rosebery (2012), including Achnanthidium minutissimum, Cyclotella ocellata, Nitzschia frustulum, and Navicula recens, exept species such Amphora pediculus, Navicula caterva and Eolimna subminuscula that occurred at Kebir-East stream or Achnanthidium saprophilum, Cyclotella meneghiniana, Fragilaria nana and Navícula cryptotenelloides at El-Hammam stream. The high chloride concentration (325 mg $\mathrm{l}^{-1}$ ) and conductivty levels (around $1575 \mu \mathrm{S} \mathrm{cm}^{-1}$ ), together with wastewater discharges 
observed near station $\mathrm{H} 2$, favored the developement of taxa adapted to such conditions. Baudrimont (1974) concluded that 206 different species recorded in Algerian aquatic systems such as wadis, chotts and sebkha were related to salt waters, concluding that freshwater streams with oligohalobious species were absent in Algeria. In our case, we noted the ocasional abundance of freshwater taxa such Cyclottela ocellata in H1 June and $\mathrm{H} 2$ August, although oligohalobous species were indeed very rare. Chaïb and Tison-Rosebery (2012) showed comparable results at Kebir-East stream, with scarce occurrence of oligohalobous species.

Table 3. Physicochemical parameters at dam of Bouhanifia (A: upstream of El-hammam) and at downstream of El-Hammam (B: upstream of Fergoug's dam). $\mathrm{O}_{2}$ sat = saturation of oxygen; $\mathrm{O}_{2}$ dis = dissolved oxygen $;$ Cond = conductivity; $\mathrm{BOD}=$ Biological oxygen demand after 5days. Source: Nationa Agency for Water Resources, Algeria (ANRH, 2010).

\begin{tabular}{|c|c|c|c|c|c|c|c|c|c|c|c|}
\hline \multirow{3}{*}{ Parameters } & \multirow{3}{*}{$\begin{array}{c}\text { Stations } \\
\text { Unit }\end{array}$} & \multicolumn{2}{|c|}{ April } & \multicolumn{2}{|c|}{ May } & \multicolumn{2}{|c|}{ June } & \multicolumn{2}{|c|}{ July } & \multicolumn{2}{|c|}{ August } \\
\hline & & \multirow[t]{2}{*}{ A } & \multirow[t]{2}{*}{ B } & \multirow[t]{2}{*}{ A } & \multirow[t]{2}{*}{ B } & \multirow[t]{2}{*}{ A } & \multirow[t]{2}{*}{ B } & \multirow[t]{2}{*}{ A } & \multirow[t]{2}{*}{ B } & \multirow[t]{2}{*}{$\mathbf{A}$} & \multirow[t]{2}{*}{ B } \\
\hline & & & & & & & & & & & \\
\hline $\mathrm{T}$ & $\mathrm{C}^{\circ}$ & 17 & 18 & 20 & 20 & 25 & - & 28 & 25 & 30 & 28 \\
\hline $\mathrm{pH}$ & & 8.1 & 7.9 & 7.9 & 7.7 & 8.2 & - & 7.9 & 7.8 & 8.1 & 7.8 \\
\hline Cond & $\mu \mathrm{S}$ cm-1 & 1270 & 3460 & 1330 & 1392 & 1204 & - & 1249 & 1281 & 1330 & 1363 \\
\hline $\mathrm{O}_{2}$ sat. & $\%$ & 82.2 & 111. & 82.6 & 69 & 128.4 & - & 69.7 & 77.7 & 87.7 & 80 \\
\hline $\mathrm{O}_{2}$ dis. & mg 1-1 & 7.7 & 0.2 & 7.3 & 6.1 & 10.4 & - & 5.4 & 6.3 & 6.6 & 6.2 \\
\hline $\mathrm{Cl}$ & mg 1-1 & 256 & 834 & 237 & 244 & 246 & - & 243 & 250 & 268 & 268 \\
\hline $\mathrm{SO}_{4}$ & mg 1-1 & 208 & 798 & 241 & 245 & 184 & - & 208 & 203 & 227 & 227 \\
\hline $\mathrm{SiO}_{2}$ & mg 1-1 & 2.3 & 2.5 & 2.2 & 2.1 & 4.5 & - & 3.1 & 3.4 & 3.9 & 4.2 \\
\hline BOD & mg 1-1 & 8.7 & 13.5 & 9.7 & 11.9 & 7.1 & - & 8.7 & 13.3 & 10.3 & 13.5 \\
\hline $\mathrm{NO}_{3}$ & mg 1-1 & 3 & 2 & 5 & 6 & 3 & - & 5 & 3 & 2 & 1 \\
\hline $\mathrm{NO}_{2}$ & mg 1-1 & 0.32 & 0.05 & 0.45 & 0.32 & 0.24 & - & 0.17 & 0.25 & 0.1 & 0.12 \\
\hline $\mathrm{PO}_{4}$ & mg 1-1 & 0.04 & 0.06 & 0.03 & 0.18 & 0.08 & - & 0.08 & 0.23 & 0.07 & 0.1 \\
\hline
\end{tabular}

Regarding the acidity levels at El-Hammam stream, the diatom communities observed consist generally of a mixture of alkaliphilous $(53.3 \%)$ and circumneutral $(46.3 \%)$ taxa. Field $\mathrm{pH}$ measurements ranged from 7.5 to 7.9 , with water temperatures betweenf 18 and $28^{\circ} \mathrm{C}$ during the study period. Acidophilous species were absent. Most taxa observed by Chaïb and Tison-Rosebery (2012) at Kebir-East stream were also alkaliphilous (70 \%), with $\mathrm{pH}$ ranging from 6.5 to 8.3 and scarce some acidophilous species. Baudrimont (1974) noted that species typical from European acid waters can adapt to alkaline waters in Algeria.

According to the classification of Van Dam et al. (1994), the dominant taxa at stations of El-Hammam stream were generally from moderately oxygenated environments -such as Nitzschia frustulum- to poorly oxygenated ones like Achnanthidium saprophilum or Nitzschia palea. Poly-oxibiontic taxa represented by Achnanthidium minutissimum were only occasional with abundance (54\%) at station $\mathrm{H} 1$ April and Cyclotella ocellata $(24 \%)$ at H1 June. A similar variation was observed by Chaïb and Tison-Rosebery (2012) at Kebir-East stream, with Achnanthidium minutissimum reaching $75 \%$ of the whole diatom community during summer.

Biological Diatom index BDI (Lenoir and Coste, 1996) had been already tested in north-eastern Algeria at Kebir-East stream by Chaïb and Tison-Rosebery (2012). BDI scores in their study were not contrasted enough, and did not appear to be in correspondence with the water quality gradient, where high conductivities and associated species tended to confuse the biological quality status; of the highest BDI value (18/20) was obtained at Ain Assel in summer 2007 by these authors, where 
Achanthidium minutissimum was dominant, and did not reflect the actual poor water quality of that station, with $\left[\mathrm{NH}_{4}{ }^{+}\right]=1 \mathrm{mg} \mathrm{l}^{-1}$ and $\left[\mathrm{PO}_{4}{ }^{3-}\right]=0.5 \mathrm{mg} \mathrm{l}^{-1}$ (Chaïb and Tison-Rosebery, 2012).

In our case, firstly we calculated Pearson's correlations between 17 diatom indices and IPO for Kebir-East wadi by using diatom counts and physicochemical results provided by the workcounts of diatom species and physicochemical variables of Chaïb and Tison-Rosebery (2012) from seven stations at summer (Table 4). The highest correlation for Kebir-East wadi at summer is for TDI: Trophic Diatom Index (Kelly and Whitton, 1995) with $\mathrm{r}=0.62$ and $\mathrm{p}=0.14$. As a result we calculated the Pearson's correlations between 16 diatom indices and TDI for El-hammam stream (Table 5) and the results give the highest correlation are respectively for TID: ROTT trophic index (Rott et al., 1999) with $\mathrm{r}=-0.95$ and $\mathrm{p}=0.004$, IDAP: Artois-Picardie Diatom Index (Prygiel et al., 1996) with r=-0.92, $\mathrm{p}=0.011$ and GDI: Generic Diatom Index (Rumeau and Coste, 1988) with $\mathrm{r}=-0.90$ and $\mathrm{p}=0.013$. Being based on a low taxonomic resolution, GDI does not give accurate results; usually GDI exhibits significant correlations against $\mathrm{PO}_{4}{ }^{3}-\mathrm{P}$ and $\mathrm{Cl}^{-}$concentrations (Blanco et al., 2007). In which the mean concentration of $\mathrm{Cl}^{-}$and $\mathrm{PO}_{4}{ }^{-}$exceed 316 and $0.1 \mathrm{mg} \mathrm{l}^{-1}$ respectively at El-Hammam stream. Fawzi et al. (2001) tested some diatoms indices at Hassar stream (Morocco), concluding that IDAP (Prygiel et al., 1996) is more suitable for the assessment of water quality in this stream. It has a fairly significant correlation with the Organic Pollution Index (IPO) and seems to incorporate saltwater taxa.

Table 4. Pearson correlation coefficients between diatom indices and organic pollution index (IPO) applied for Kebir-Est stream [results are calculated by using Data counts of diatom species and physicochemical variables was trailed from work of Chaib \& TisonRosebery (2012) of seven sampling stations on the Kebir-East stream in summer period]. SLA: Sládeček's Index; DESCY:Descy's Pollution Index; IDSE: Leclerq; SHE: Schiefele and Schreiner's index; WAT: Watanabe index; TDI: Trophic Diatom Index; \%PT:

Pourcentage of Pollution Tolerant Taxa; GDI: Generic Diatom Index; CEC: Commission of Economic al Community Index; SPI: Specific Pollution Sensitivity Index; BDI: Biological Diatom Index; IDAP: Artois-Picardie Diatom Index; EPI-D: Eutrophication/Pollution Index; DI_CH: Hurlimann Suisse; IDP: Pampean Diatom Index; LOBO: LOBO index; SID: Saprobic Index and TID: Rott Trophic Index. IPO: Organic Pollution index "Indice de Pollution Organique”.

\begin{tabular}{|c|ccccccccccccccccc|}
\hline Indices & SLA & DESCY & IDSE/5 & SHE & WAT & TDI & GDI & CEE & SPI & BDI & IDAP & EPI-D & DI_CH & IDP & LOBO & SID & TID \\
\hline IP0 & -0.37 & 0.31 & -0.26 & -0.21 & -0.18 & $\mathbf{0 . 6 2 *}$ & -0.12 & -0.14 & -0.15 & -0.21 & -0.14 & -0.51 & -0.28 & -0.3 & -0.54 & -0.46 & -0.57 \\
\hline
\end{tabular}

Table 5. Pearson correlation coefficients between diatom indices and Trophic Diatom Index (TID) applied for El-Hammam stream.

\begin{tabular}{|c|cccccccccccccccc|}
\hline Indices & SLA & DESCY & IDSE/5 & SHE & WAT & GDI & CEE & SPI & BDI & IDAP & EPI-D & DI_CH & IDP & LOBO & SID & IID \\
\hline $\begin{array}{c}\text { Trophic Diatom } \\
\text { Index (TDI) }\end{array}$ & -0.58 & -0.44 & -0.66 & -0.55 & -0.06 & -0.9 & -0.8 & -0.87 & -0.87 & -0.92 & -0.69 & 0.03 & -0.68 & -0.33 & -0.24 & $-0.95^{*}$ \\
\hline
\end{tabular}

Tested indices at El-hammam stream (Table 6) show that water quality indicated by TDI and TID at station H1 in April reflect a water quality with a little degree of eutrophication, being eutrophic in June and August with some evidence of organic 
pollution $(\mathrm{PT} \%=21-40 \%)$. While station $\mathrm{H} 2$ in April and June show a high degree of eutrophication with organic pollution likely to contribute significantly to eutrophication of site $(\mathrm{PT} \%=41-60)$, being fairly eutophic at August with free of significant organic pollution $(\mathrm{PT} \%=<20)$. The station $\mathrm{H} 2$ was frequently influenced by fluctuating urban wastewater discharges from Bouhanifia while station $\mathrm{H} 1$ near to downstream of the dam of Bouhanifia $(2.2 \mathrm{Km})$ was less influenced by urban discharges.

Table 6. Values of diatom indices applied for stations at El-Hammam stream.

\begin{tabular}{|c|cccccc|}
\hline \multirow{2}{*}{ Indices Stations } & \multicolumn{3}{|c}{ Avril } & \multicolumn{2}{c}{ Juin } & Aout \\
\cline { 2 - 7 } & H1 & H2 & H1 & H2 & H1 & H2 \\
\hline SLA & 14.3 & 9.3 & 10.9 & 9 & 9.2 & 9.4 \\
DESCY & 14.8 & 10.3 & 9.9 & 6.3 & 8.4 & 7.8 \\
IDSE/5 & 4.24 & 2.83 & 3.16 & 2.72 & 2.88 & 2.96 \\
SHE & 13.4 & 6.7 & 9.2 & 5.4 & 8.5 & 6.6 \\
WAT & 14.7 & 10.2 & 9.5 & 7.6 & 7.8 & 4.2 \\
TDI & 36 & 85 & 71.8 & 82.5 & 68.8 & 35.4 \\
\%PT & 26.4 & 42.2 & 38.9 & 57.4 & 40.4 & 11.4 \\
GDI & 12.7 & 9.3 & 8.5 & 5.9 & 9 & 14.6 \\
CEE & 13.9 & 4 & 6.7 & 2.7 & 6.3 & 7.1 \\
SPI & 13.9 & 7.5 & 7 & 4 & 6.8 & 10.5 \\
BDI & 14.2 & 10.1 & 10.3 & 7.6 & 10 & 12.1 \\
IDAP & 12.9 & 5.1 & 9.2 & 6.4 & 8.9 & 10.7 \\
EPI-D & 15.4 & 7.5 & 11.7 & 8 & 8.6 & 9.8 \\
DI_CH & 10.2 & 7.3 & 10 & 5.2 & 5.8 & 3.2 \\
IDP & 13.8 & 7.7 & 8.8 & 7.8 & 8.2 & 8.5 \\
LOBO & 19.7 & 14.5 & 17.2 & 19.3 & 14.7 & 16.5 \\
SID & 11.7 & 9.4 & 10.2 & 9.3 & 10.1 & 8.5 \\
TID & 7.8 & 4 & 5.9 & 4.8 & 5.2 & 7.1 \\
\hline
\end{tabular}

Sites $\mathrm{C} 1$ and $\mathrm{C} 2$ at the estuary of wadi Cheliff river had in general the same taxa composition during April, June and August, including Berkeleya sp. 1, Berkeleya sp. 2, Amphora sp. Navicula phyllepta, Achnanthidium minutissimum var. gracillimum and Nitzschia incerta. These sites there are not affected by effluent discharges or wastewater inflows between sites $\mathrm{C} 1$ and $\mathrm{C} 2$. This zone being characterized by a high input of inorganic nitrogen and phosphorus (Kies, 2009).

Correspondence analysis (CA) applied to diatom abundance data in relation with the different sampled stations is represented on a factorial symmetrical plot of two axes (Fig. 2 and 3) with the maximum of inertia (57.91\%) for El-Hammam stream analysis and $84.05 \%$ for estuary Cheliff river ( $\mathrm{p}<0.001$ ). CA applied for species densities in ElHammam stream $(\mathrm{F} 1=33.78 \%, \mathrm{~F} 2=24.04 \%)$ show that the $\mathrm{x}$-axis separated the stations $\mathrm{H} 2$ April and $\mathrm{H} 2$ August from the others (Fig. 2). Conversely, the y-axis distinguishes stations H2 April, H1 June and H2 June from H1 April, H1 August and $\mathrm{H} 2$ August. Site $\mathrm{H} 2$ at El-hammam stream was characterized by taxa singular taxonomic composition in April, June and August, this maybe due to urban wastewater discharge and a unstable flow regime caused by water discharges from the dam of Bouhanifia followed by dry summer periods. All these factors were unstable during the 
study period, but site $\mathrm{H} 1$, near to the downstream of dam of Bouhanifia and not influenced by signficant urban waswater discharges, remained more stable, with similar diatom communities along the study period.

At the the estuary of Cheliff river, $\mathrm{CA}(\mathrm{F} 1=73.44 \%, \mathrm{~F} 2=10.62 \%)$ shows that first two axes discriminate stations $\mathrm{C} 1$ and $\mathrm{C} 2$ monthly (Fig. 3). The stations $\mathrm{C} 1$ and $\mathrm{C} 2$ June, and $\mathrm{C} 1$ and $\mathrm{C} 2$ August, appear very close, while C1 and C2 April are more distant, this can be related to the fact that diatom community in April $\mathrm{C} 1$, near to sea water, was more influenced by sea intrusions during this month.

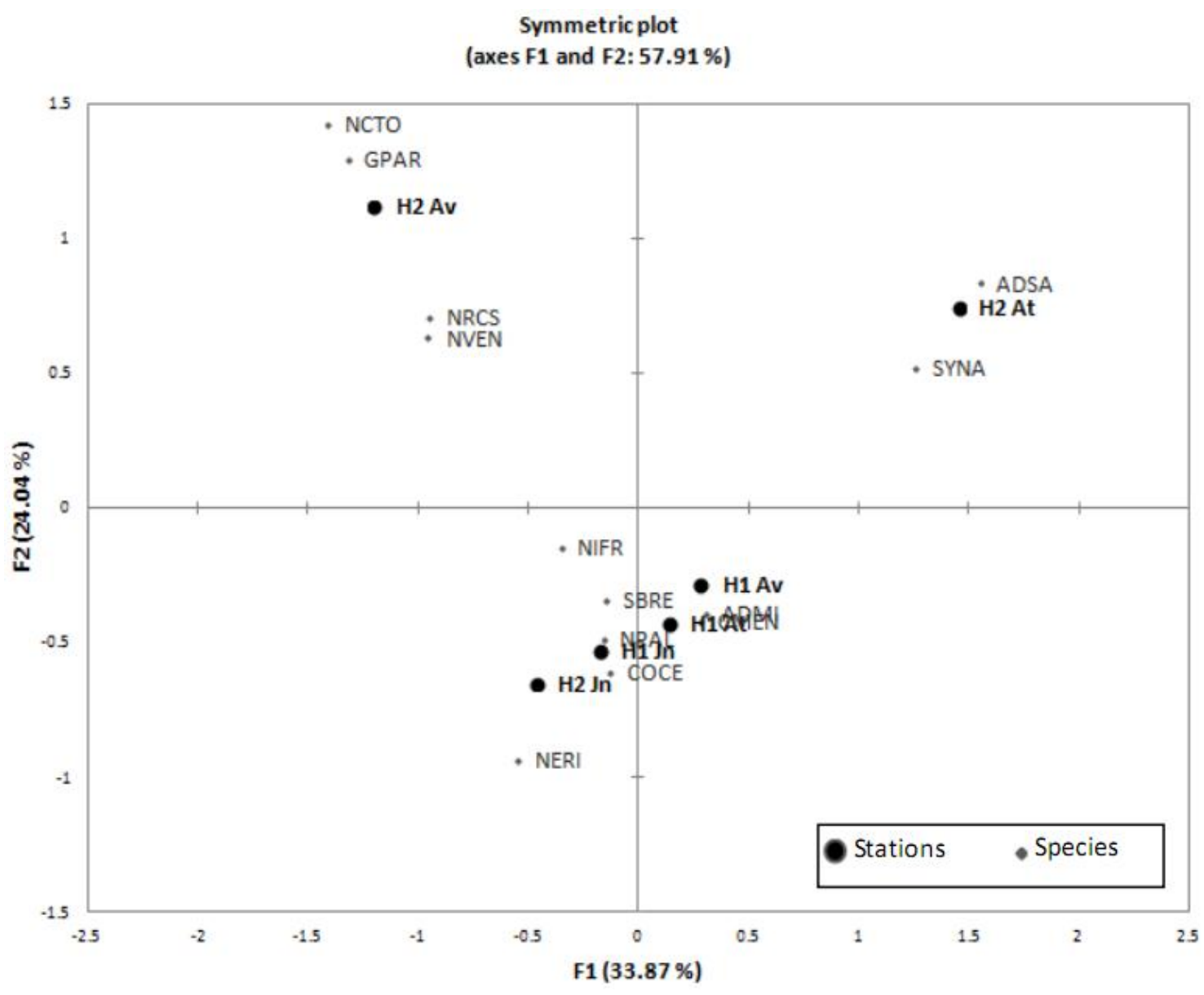

Figure 2. Factorial plot of the Classification Analysis (CA) applied to the distributions of 13 species densities (abundance $>5 \%$ ) on sampled sites of El-Hammam stream H1 and H2: April (H1 av; H2 av), June (H1 Jn; H2 Jn), and H1 August (H1 At; H2 At). Each species was coded by four letters of scientific name of the species ADMI: Achnanthidium minutissimum. ADSA: Achnanthidium saprophilum. CMEN: Cyclotella meneghiniana. COCE: Cyclotella ocellata. SYNA: Fragilaria nana. GPAR: Gomphonema parvulum. NCTO: Navicula cryptotenelloides. NERI: Navicula erifuga. NRCS: Navicula recens. NVEN: Navicula veneta. NIFR: Nitzschia frustulum. NPAL: Nitzschia palea. SBRE: Surirella brebissonii. AMGR: Achnanthes minutissima var gracillima. ACOF: Amphora coffeaeformis. A.sp: Amphora sp, B.sp1: Berkeleya sp. 1 (rutilans?). B.sp2: Berkeleya sp. 2 (scopulorum?). NPHY: Navicula phyllepta. NZCL: Cylindrotheca closterium. NREV: Nitzschia incerta. 


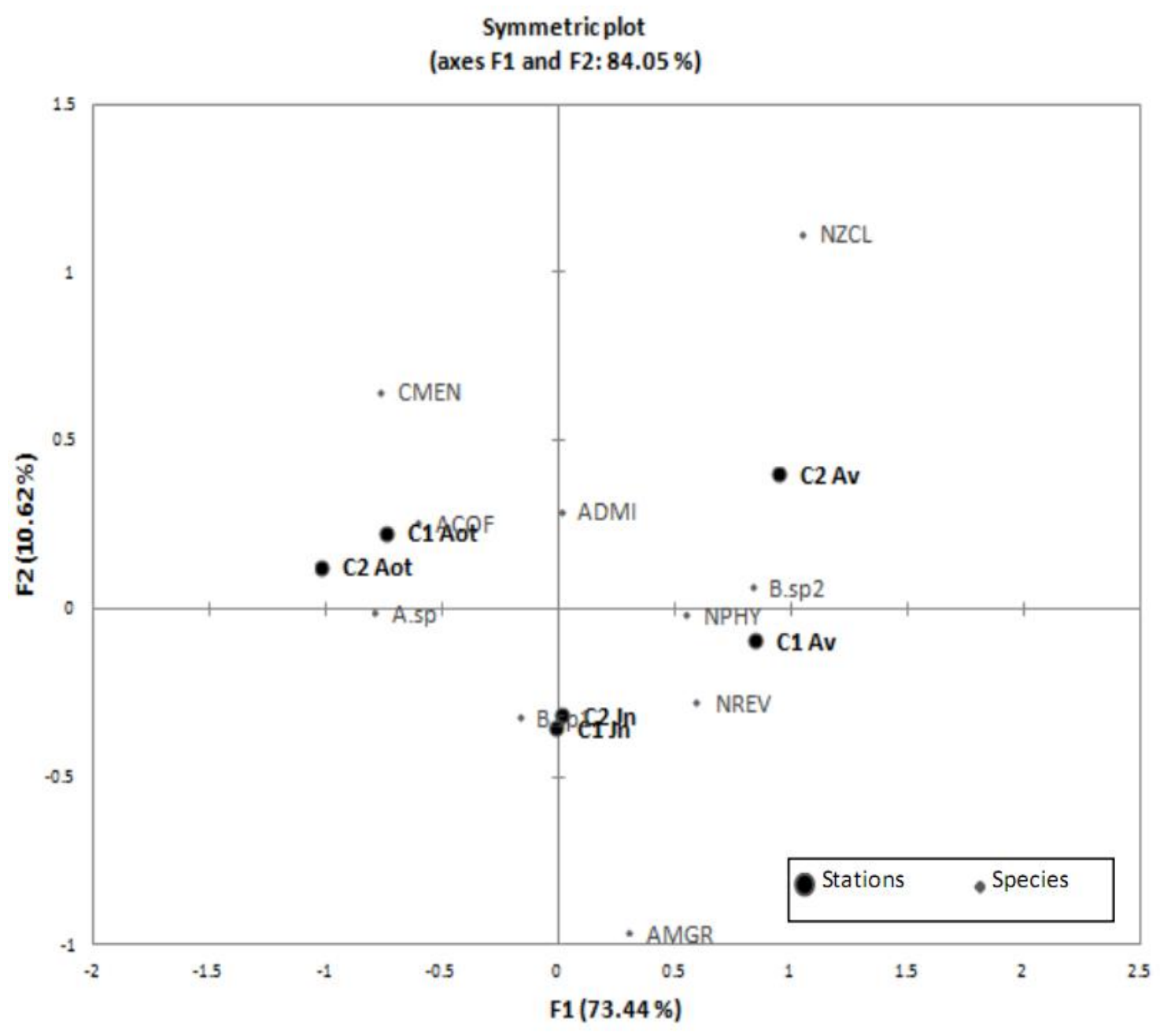

Figure 3. Factorial plot of the Classification Analysis (CA) applied to the distributions of 10 taxa densities (abundance >5\%) on sampled sites of estuary of Cheliff river C1 and C2: April (C1 av; C2 av), June (C1 Jn; C2 Jn), and C1 August (C1 At; C2 At). Each species was coded by four letters of scientific name of the species (Fig. 2).

\section{REFERENCES}

[1] Addinosoft (2013): XLstat: Data analysis and statistical application available for Microsoft Excel. [Computer software], United Kingdom. Retrieved from http://www.xlstat.com.

[2] Al-Asadi, M. S., Randerson, P., Benson-Evans, K. (2006): Phytoplankton population dynamics in three west Algerian rivers: I. The river Cheliff and its tributary, the river mina. - Marina Mesopotamica Online 1:48 - 72 .

[3] Amosse, A. (1941) : Algues des eaux continentales africaines. II: Diatomées du Sahara septentrional et central. - Bull. Soc. Hist. Nat. Afr. Nord. 32: 126-152.

[4] ANRH (2010): National Agency of Water Resources. Bulletins d'analyses de l'eau année 2010. Algeria, Retrieved January, 2011, from http://www.anrh.dz

[5] Bahroun, S., Kherici Bousnoubra, H. (2011): Evaluation de l'indice de pollution organique dans les eaux naturelles. Cas de la région d'El Tarf (Nord Est algérien). Larhyss Journal. 9: 171-178. 
[6] Bate, G. C., Smailes, P. A., Adams, J. B. (2004): Benthic diatoms in the rivers and estuaries of South Africa. University of Port Elizabeth. - Water Research Commission Report, South Africa. No. TT, 234/04.

[7] Baudrimont, R. (1970): Contribution à l'étude de la flore algologique de l'Algérie. I. Hydrobiologie du Chott Ech Chergui. - Bull. Soc. Hist. Nat. Afr. Nord. 61: 155-167.

[8] Baudrimont, R. (1971a): La recherche algologique en Algérie. Historique perspectives et bibliographie. - Bull. Soc. Hist. Nat. Afr. Nord. 62 (3-4): 27-37.

[9] Baudrimont, R. (1974): Recherches sur les Diatomées des eaux continentales de l'Algérie. Ecologie et paléo-écologie. Mémoire, Soc. Hist. Nat. Afr. Nord, nouvelle série 12: 265.

[10] Blanco, S., Bécares, E., Cauchie, H. M., Hoffmann, L., Ector, L. (2007): Comparison of biotic indices for water quality diagnosis in the Duero Basin (Spain). - Archiv für Hydrobiologie. Supplement Large Rivers. 17:267-286.

[11] Blanco, S., Cejudo-Figueiras, C., Álvarez-Blanco, I., Bécares, E., Hoffmann, L., Ector, L. (2010): Atlas de las diatomeas de la cuenca del Duero - Diatom atlas of the Duero basin. - Área de Publicaciones, Universidad de León, León.

[12] Chaïb, N., Alfarhan, A. H., Al-Rasheid, K. A. S., Samraoui, B. (2011): Environmental determinants of diatom assemblages along a north African wadi, the Kebir-East, northeast Algeria. - Journal of Limnology. 70(1):33-40.

[13] Chaïb, N., Tison-Rosebery, J. (2012): Water quality assessment and application of the biological diatom index in the Kebir-East wadi, Algeria. - African Journal of Aquatic Science. 37(1): 59-69.

[14] Ehrenberg, C. G. (1854): Mikrogeologie: Das Erden und Felsen schaffende Wirken des unsichtbar kleinen selbständigen Lebens auf der Erde. Leipzig: L. Voss. Afrika. 185-286.

[15] European Union, (2000): Directive 2000/60/EC of the European Parliament and of the Council of 23 October 2000 establishing a framework for Community action in the field of water policy. - Official Journal of the European Communities L327: 1-73.

[16] Fawzi, B., Chlaida, M., Oubraim, S., Loudiki, M., Sabour, B. Bouzidi, A. (2001): Application de certains indices diatomiques à un cours d'eau marocain: Oued Hassar. Revue des sciences de l'eau / Journal of Water Science 14:73-89.

[17] Hasle, G. R., Fryxell, G.R. (1970): Diatoms: cleaning and mounting forlight and electron microscopy. - Transactions of the American Microscopical Society 89:469-474.

[18] Kelly, M. G., Whitton, B. A. (1995): The trophic diatom index: a new index for monitoring eutrophication in rivers. - Journal of Applied Phycology 7:433-444.

[19] Kelly, M.G., Cazaubon, A., Coring, E., Dell'uomo, A., Ector, L., et al. (1998): Recommendations for the routine sampling of diatoms for water quality assessments in Europe. - Journal of Applied Phycology 10:215-224.

[20] Kies, F. (2009): Identification, et validation d'indicateurs de gestion pour le développement durable de l'écosystème marin à Mostaghanem (Algerie). Recueil du séminaire national sur l'environnement et l'industrie : en jeux et défis. - Sheraton d'Oran, 27- 28 janvier 2009, Algerie, 19-27 pp.

[21] Krammer, K., Lange-Bertalot, H. (1986): Bacillariophyceae, Teil 1, Naviculaceae. Band 2/1: Süßwasserflora von Mitteleuropa (begründet von A. Pascher) - Gustav Fischer, Stuttgart.

[22] Krammer, K., Lange-Bertalot, H. (1988): Bacillariophyceae, Teil 2, Epithemiaceae, Bacillariaceae, Surirellaceae. Band 2/2: Süßwasserflora von Mitteleuropa (begründet von A. Pascher) - Gustav Fischer, Stuttgart.

[23] Krammer, K., Lange-Bertalot, H. (1991a): Bacillariophyceae, Teil 3, Centrales, Fragilariaceae, Eunotiaceae. Band 2/3: Süßwasserflora von Mitteleuropa (begründet von A. Pascher) - Gustav Fischer, Stuttgart.

[24] Krammer, K., Lange-Bertalot, H. (1991b): Bacillariophyceae, Teil 4, Achnanthaceae, Kritische Ergänzungen $\mathrm{zu}$ Navicula (Lineolatae) und Gomphonema Gesamtliteraturverzeichnis Teil 1-4. . Band 2/4: Süßwasserflora von Mitteleuropa (begründet von A. Pascher) - Gustav Fischer, Stuttgart.

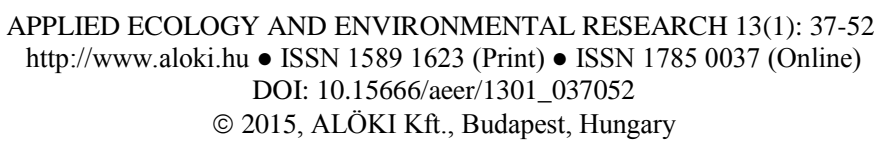


[25] Krammer, K., Lange-Bertalot, H. (2000): Süßwasserflora von Mitteleuropa. Band 2/5. Bacillariophyceae. Part 5. English and french translation of the Keys. - In: Spektrum Akademischer Verlag GmbH (ed.), Sußwasserflora von Mitteleuropa, Heidelberg-Berlin.

[26] Lange-Bertalot, H., Fumanti, B., Cavacini, P., Tagliaventi, N. (2009): The genus Navigiolum (Bacillariophyceae) in Mediterranean and North African rock pool habitats: description of four new species from Algeria. - Fottea. 2:179 -185.

[27] Lavoie, I., Hamilton, P. B., Campeau, S., Grenier, M., Dillon, P. J. (2008): Guide d'identification des diatomées des rivières de l'Est du Canada - Presses de l'Université du Québec, Canada.

[28] Leclercq, L., Maquet, B. (1987): Deux nouveaux indices chimiques et diatomiques de qualité d'eau courante. Application au Samson et à ses affluents (Bassin de la Meuse belge). Comparaison avec d'autres indices chimiques, biocénotiques et diatomiques. Document de travail, Institut Royal des Sciences Naturelles de Belgique. Bruxelles, No. 38.

[29] Lecointe, C., Coste, M, Prygiel, J. (1993): Omnidia: Software for taxonomy, calculation of diatom indices and inventories management. - Hydrobiologia 270:509-513.

[30] Lenoir, A., Coste, M. (1996): Development of a practical diatom index of overall water quality applicable to the French national water board network. - In: B.A. Whitton and E. Rott (Eds.), Use of Algae for Monitoring Rivers II. Institut fur Botanik. Univ. Innsbruck, Innsbruck, 29-43.

[31] Montagne, C. (1846): Flore d'Algérie. Ordo I. Phyceae Fries. In: Exploration scientifique de l'Algérie pendant les années 1840, 1841, 1842. Durieu De Maisonneuve, M.C. (Eds.), Sciences physiques. Botanique. Cryptogamie 1:1-197.

[32] Petit, P. (1895): Catalogue des Diatomacées du Maroc, d'Algérie et de Tunisie, Annexe à la flore de Battandier et Trubat - Alger, Jourdan.

[33] Prygiel, J., Leveque, L, Iserentant, R. (1996): Un nouvel indice diatomique pratique pour l'évaluation de la qualité des eaux en réseau de surveillance. - Revue des Sciences de l'Eau 1:97-113.

[34] Prygiel, J., Coste, M. (2000): Guide méthodologique pour la mise en œuvre de l'Indice Biologique Diatomées NF T 90-354. - Agences de l'Eau-Cemagref, France.

[35] Rott, E., Pipp, E., Pfister, P., Van Dam, H., Ortler, K.., Binder, N, Pall, K. (1999): Indikationslisten für Aufwuchsalgen in österreichischen Fließgewässern. Teil 2: Trophieindikation sowie geochemische Präferenz, taxonomische und toxikologische Anmerkungen. Bundesministerium für Land-und Forstwirtschaft, Wasserwirtschaftskataster, Wien.

[36] Rovira, L., Trobajo, R., Ibáñez, C. (2009): Periphytic diatom community in a Mediterranean salt wedge estuary: the Ebro Estuary (NE Iberian Peninsula). - Acta Botanica Croatica 68:285-300.

[37] Rumeau, A., Coste, M. (1988): Initiation à la systématique des diatomées d'eau douce. Pour l'utilisation pratique d'un indice diatomique générique. - Bull. Fr. Pêche Piscic. 309: $1-69$.

[38] Taylor, J. C., Harding, W. R., Archibald, C. G. M. (2007a): An illustrated guide to some common diatom species from South Africa. - Water Research Commission, Report, South Africa, No. TT, 282-07.

[39] Taylor, J. C., Harding, W. R., Archibald, C. G. M. (2007b): A methods manual for the collection, preparation and analysis of diatom sample. Version 1.0. - Water Research Commission Report, South Africa, No.TT, 281-07.

[40] Van Dam, H., Mertens, A., Sinkeldam, J. (1994): A coded checklist and ecological indication values of freshwater diatoms from The Netherlands. - Netherlands Journal of Aquatic Ecology 28:117-133. 